\title{
CONTROL OF ANGULAR BACTERIAL LEAF SPOT DISEASE OF WATERMELON USING ADVANCED COPPER COMPOSITES
}

\section{Ebrahim ${ }^{1}$, M.A.; Wafaa M. Abd El-Sayed ${ }^{1}$; N.Y. Abd El-Ghafar'; M.L. Paret ${ }^{3}$; M. Young ${ }^{4}$ S. Santra ${ }^{4}$ and J.B. Jones ${ }^{2}$}

1- Plant Pathology Dept., Fac. of Agric., Ain Shams Univ., Cairo, Egypt.

2- Plant Pathology Dept., Univ. of Florida, Gainesville, FL., USA.

3- Plant Pathology Dept., North Florida Research and Education Center, Univ. of Florida, Quincy, FL., USA.

4- Chemistry Dept., Nano Science Technology Center, Materials Sci. and Engineering and Burnett School of Biomedical Sciences, Univ. of Central Florida, Orlando, FL, USA

Keywords: Angular leaf spot, Pseudomonas syringae, Kocide 3000 , watermelon

\section{ABSTRACT}

Angular leaf spot, caused by $P$. syringae, is one of the most important bacterial disease of watermelon. For disease management, growers rely on copper bactericides, which are effective after the first two weeks of transplanting, while they couldn't be applied before that due to the high phytotoxicity they may cause to the plant. This study was undertaken to evaluate the antibacterial activity of three new copper composites, core-shell copper (CS-Cu), multivalent copper (MV-Cu), and fixed quaternary ammonium copper (FQ-Cu), as potential treatments to control the disease before the emergence of the first true leaf where copper is not available, and to identify the possibility of applying the newly designed copper composites during that period to significantly reduce secondary dispersal of disease inoculum. In vitro, $50 \mu \mathrm{g} / \mathrm{ml}$ of metallic copper from MV-Cu and FQ-Cu significantly reduced the $P$. syringae populations after $2 \mathrm{hrs}$ of exposure compared to the untreated control $(\mathrm{P}=$ 0.05 ) and were more effective than using the Kocide $^{\circledR} 3000$. Greenhouse studies demonstrated that $\mathrm{MV}-\mathrm{Cu}$ and $\mathrm{FQ}-\mathrm{Cu}$ significantly reduced the disease incidence compared to both Mankozeb+ Kocide $^{\circledR} 3000$ and untreated control when using the seed inoculation method. In contrast, none of the nano-composites significantly reduced disease incidence when using the spray inoculation method. MV-Cu and FQ-Cu managed to significantly reduce seedling to seedling disease transmission under greenhouse conditions $(P=0.05)$. This study highlights that copper composites have the potential to manage $P$. syringae in the first two weeks of transplanting and reducing the contamination rate from infected to healthy transplants

\section{INTRODUCTION}

Watermelon (Citrullus lanatus) is being widely used in many countries all around the world including Egypt and the United States of America for domestic consumption and exportation. Egypt is considered one of the top watermelon producing countries in the world as of 2014 (FAOSTAT, 2017). Also, Egypt is one of the highest watermelons seed exporting countries to the United States (USDA, 2013). Watermelon production is being affected by several fungal, bacterial and viral diseases (Bhat et al 2010; Fatmi et al 2008; Morris et al 2000).

One of the most important bacterial diseases that infect watermelons is angular bacterial leaf spot caused by Pseudomonas syringae. It can cause losses to watermelons especially under wet and humid conditions (Bhat et al 2010 and Riffaud et al 2003). This disease and some other similar diseases could become epidemic and cause disease incidence up to 80-100\%, especially if disease is severe in the early stages of fruit development which can cause fruit drop, and could also cause up to $100 \%$ yield loss (Harighi, 2007; Langston Jr et al 2003 and Morris et al 2000). The disease is present in Egypt and Florida where 
the favorable conditions are available specially when cultivating under greenhouse conditions. The symptoms of the disease could appear on many parts of the plant, including leaves, stems, and fruits (El Sadek et al 1992 and Mullin \& Schenck, 1963).

In Egypt and southeastern America, watermelon seedlings may face cold temperatures as planting dates are from mid-December to April and fruits are harvested from May to July (Elwakil and Mossler, 2013). The causal organism associated with recent outbreaks of angular leaf spot in watermelon in Florida is Pseudomonas syringae (Newberry et al 2015). The nomenclature of the causal agent had been changed many times in the past years, as $P$. syringae pv. lachrymans was considered the causal organism until it was proven genetically that there are many other $P$. syringae pathovars can cause the disease. The pathogen has a wide host range in Cucurbitaceae such as watermelon (Citrullus lanatus), squash (Cucurbita maxima), cantaloupe (Cucumis melo) and cucumber (Cucumis sativus) (Sedighian et al 2014).

The disease was first recorded in Egypt in cucumber greenhouses in El-Minia governorate in 1989 (El Sadek et al 1992). In Florida, the first report of the disease was in 1963 on several commercial watermelon fields (Mullin and Schenck, 1963). The disease was also reported during the spring season of 2013, then it was discovered in Georgia in 2015, and in North Carolina in 2016 (Newberry et al 2015 and Quesada-Ocampo, 2016). The angular bacterial leaf spot of watermelon is considered an emerging disease in the last few years in southeastern United States. In 2013 and 2014, there were disease outbreaks that caused transplant losses due to a severe blighting at the early stages of the transplant production.

Zitter et al (1996) mentioned that disease symptoms may be different from one case to another depending on the environmental conditions and the host range.

Although some other cucurbit diseases caused by Pseudomonas syringae are also called angular leaf spot (Williams, 1996), depending on the host and the shape of the symptoms, the common disease name could also be either bacterial blight or bacterial leaf spot (Lamichhane et al 2015).

Many control approaches have been attempted to control the disease including plant growthpromoting rhizobacteria (PGPR), where they have shown a significant disease control and were used to induce systemic resistance in cucumber plants using strains of compared to the noninduced con- trol plants, although, using PGPRs for disease control still faces many challenges as the change of the environmental conditions such as the temperature, soil acidity and salinity could cause loss of the effectiveness of these bacteria (Gopalakrishnan et al 2014). One of the disease control methods is the early detection of the pathogen in seeds using PCR methods to avoid introducing contaminated seeds into some areas (Shila et al 2013). Although, most of these methods have a low level of sensitivity and further progress is needed to increase their sensitivity (Fanelli et al 2007).

Copper bactericides are one of the most famous and effective materials for controlling bacterial diseases. They have shown significant disease control and were suggested as a chemical control for some cucurbits against angular leaf spot (Williams, 1996). However, Bhat et al (2010) reported that economical control of the disease on cucumber and cantaloupe could not be achieved using those copper bactericides. The need for good compounds to control the disease is increasing day after day specially that there are no available resistant watermelon varieties to angular leaf spot of cucurbits caused by $P$. syringae. Other copperbased bactericides are commercially available, such as copper (II) oxychloride, copper (II) sulphate, or copper (II) hydroxide (Young and Santra, 2014). A copper bactericide called Kocide ${ }^{\circledR}$ 3000 (DuPont ${ }^{\mathrm{TM}}$, Wilmington, DE), contains micron-sized metallic copper in the form of copper (II) hydroxide at $5 \mu \mathrm{M}$ (Nufram, 2013). Gunawan et al (2011), and Jiang et al (2009) Showed that micron-sized metallic compounds have lower antibacterial activity compared to their nanometer-sized counterparts, as the antibacterial activity increased when decreasing the size of the metallic particles used in these studies. So, it could be said that the high antibacterial activity of the nanoparticles is referred to the high surface to volume ratio and their small size, which both allow nanoparticles to go through the bacterial membranes and release more metal ions more efficiently than their micronsized counterparts (Baker et al 2005 and Morones et al 2005).

The particles for some copper compounds are highly hydrophobic which may cause them to aggregate in water which causes a low antimicrobial activity due to the reduction of the total surface area of copper particles. So, three advanced copper compounds (fixed quaternary ammonium copper, FQ-Cu; multivalent copper, MV-Cu; and coreshell copper, CS-Cu) were designed to stop cop- 
per particles from aggregation and to improve the copper particles antimicrobial efficacy (Maniprasad and Santra, 2012 and Young \& Santra, 2014).

Young and Santra (2014) reported that to reduce particle-particle aggregation, copper particles were embedded in hydrophilic silica gel matrix as at slightly basic to neutral $\mathrm{pH}$ conditions, sol-gel silica is negatively charged and hydrophilic. Santra (2012) reported that aggregation of copper particles is prevented when embedded into the silica gel, also, it increases the availability of copper ions. Based on the previous reasons, the copper composites used in this study could have better antimicrobial activity than the micron-sized metallic copper against copper-tolerant Pseudomonas strains.

So, the objectives of this study were to determine the antimicrobial efficacy of the newly designed copper compounds (FQ-Cu, MV-Cu, and $\mathrm{CS}-\mathrm{Cu}$ ) and compare it to the micron-sized metallic copper for (i) the in vitro reduction of copper sensitive and copper tolerant strains of $P$. syringae; ii) To identify the possibility of applying the newly designed copper composities during the emergence period (before the $1^{\text {st }}$ true leaf) where copper is not available for controlling $P$. syringae and significantly reducing secondary dispersal of inoculum.

\section{MATERIALS AND METHODS}

\section{Bactrial strains}

Pseudomonas syringae strain 13-1 was obtained from the department of Plant Pathology, University of Florida, and was selected for this experiment as it is highly pathogenic on watermelon, cantaloupe and squash while the copper tolerant $P$. syringae strain A1513 was used as a control for the in vitro assay of the nano-sized composites. Strains were stored in sterile $30 \%$ glycerol for longterm storage at $-80^{\circ} \mathrm{C}$, and on King's $\mathrm{B}$ medium for experiments and short-term storage.

For the easy detection of the $P$. syringae strain 13-1 from the greenhouse, the isolate was mutated to grow on nutrient agar medium amended with $100 \mu \mathrm{g} / \mathrm{ml}$ of Rifamycin antibiotic. Isolate was grown on nutrient agar plates for $24 \mathrm{~h}$ at $28^{\circ} \mathrm{C}$. Bacterial cells were then removed from the plates, suspended in sterilized tap water and the bacterial suspensions were adjusted to $A 600=0.3$ which is equivalent to $5 \times 10^{8} \mathrm{CFU} / \mathrm{ml}$. Hundred microliters of the suspension were then spread-plated onto nu- trient agar plates amended with $100 \mu \mathrm{g} / \mathrm{ml}$ of $\mathrm{Ri}$ famycin antibiotic. Plates were incubated at $28^{\circ} \mathrm{C}$ for 4 to 5 days.

\section{Design of advanced copper composites}

Three advanced copper composites (CS-Cu, $\mathrm{MV}-\mathrm{Cu}$, and FQ-Cu) were designed to improve overall antimicrobial efficacy of metallic copper. In all these composites, copper particles are embedded in a hydrophilic, porous silica gel matrix to reduce particle-particle aggregation during the solgel synthesis process (Young and Santra, 2014). In short, copper is chelated by the silica gel and partly converted to crystalline copper hydroxide/oxide particles at $\mathrm{pH} 7.5$ and above. The silica layer around copper crystals minimizes particle aggregation and improves overall dispersibility of copper composites. As previously described in Maniprasad and Santra (2012), colloidal silica particles (Stöber et al 1968) are used as a filler to further disperse copper-silica gel particles in the CS-Cu composite. In MV-Cu composite, copper is present in mixed-valence states $(+1$ and +2 oxidation states) along with metallic $\mathrm{Zn}$ ( 10 wt\%) (Young and Santra, 2014). As previously described in Santra et al (2014), the silica gel in the FQ-Cu composite is embedded with both a Quaternary Ammonium Compound (Fixed-Quat) and metallic copper. The purpose of using Fixed-Quat is to i) further improve the dispersibility of coppersilica gel particles, and ii) improve overall antimicrobial efficacy of the materials through additional biocidal activity of Fixed-Quat. In all three of the copper composites, copper ions are released in a slow manner. Thus, all these copper composites can be considered somewhere between the soluble (such as copper salts) and insoluble (such as copper oxides and copper hydroxides) forms of copper.

\section{In vitro assays}

The bacterial strains were grown on $\mathrm{KB}$ plates for $24 \mathrm{~h}$ at $28^{\circ} \mathrm{C}$, then were transferred to NA plates containing $20 \mu \mathrm{g} / \mathrm{ml}$ of copper in the form of copper (II) sulfate pentahydrate $\left(\mathrm{CuSO}_{4} .5 \mathrm{H}_{2} \mathrm{O}\right)$ (Sigma-Aldrich) to pre-induce the bacteria against copper, plates were incubated for $24 \mathrm{~h}$ at $28^{\circ} \mathrm{C}$. Bacterial cells were removed from the plates, suspended in sterilized tap water and the bacterial suspensions were adjusted to $A 600=0.3$ which is equivalent to $5 \times 10^{8} \mathrm{CFU} / \mathrm{ml}$, then suspensions were serial diluted to $10^{5} \mathrm{CFU} / \mathrm{ml}$. 
Twenty microliters of each bacterial suspension for each strain were transferred to sterile glass tubes, containing $2 \mathrm{ml}$ of: Core-Shell copper (CS$\mathrm{Cu}$ ), Multivalent (MV-Cu), fixed quaternary ammonium copper (FQ-Cu) and Kocide ${ }^{\circledR} 3000$ (DuPont, Wilmington, DE) at $50,100,200$ and $500 \mathrm{mg} / \mathrm{ml}$ of metallic copper. Kocide ${ }^{\circledR} 3000$ was prepared from a stock suspension of $1 \mathrm{mg} / \mathrm{ml}$ of metallic copper in sterilized magnesium sulphate hepta hydrate $\left(\mathrm{MgSO}_{4} .7 \mathrm{H}_{2} \mathrm{O}\right)$ solution in deionized water, after leaving on a shaker for 4 hours at $250 \mathrm{rpm} / \mathrm{min}$ at room temperature, and filtering through $0.2 \mu \mathrm{m}$ pore diameter filter paper. Kocide ${ }^{\circledR} 3000$ contains $30 \%$ metallic copper in the form of copper hydroxide $\left(\mathrm{Cu}(\mathrm{OH})_{2}\right)$. Also, $20 \mu \mathrm{l}$ of each bacterial suspension were added to three sterilized glass tubes containing $2 \mathrm{ml}$ of sterilized $\mathrm{MgSO}_{4} .7 \mathrm{H}_{2} \mathrm{O}$ in tap water to be used as controls. The tubes were then incubated at $28^{\circ} \mathrm{C}$ on a shaker (250 rpm/min) for 2 h. Then, $50 \mu \mathrm{l}$ from each tube were plated on NA plates to determine the bacterial populations. The plates were incubated for $48 \mathrm{~h}$ at $28^{\circ} \mathrm{C}$; then, the CFU per milliliter was calculated by counting the number of colonies formed on each plate. Three replicates per each treatment were done, and the experiment was conducted twice.

\section{Validation of seed inoculation method}

The mutated Pseudomonas syringae strain 131 was stored at $-80^{\circ} \mathrm{C}$ in $15 \%$ glycerol and cultured on King's medium B for $48 \mathrm{~h}$ at $28^{\circ} \mathrm{C}$ as needed. For inoculum preparation, a bacterial growth was harvested from a $24 \mathrm{~h}$ culture, and suspended in sterilized tap water. Bacterial concentration was adjusted using a spectrophotometer to approximately $1 \times 10^{8} \mathrm{CFU} / \mathrm{ml}(\mathrm{A} 600=0.3)$. The bacterial suspension was diluted to $1 \times 10^{7} \mathrm{CFU} / \mathrm{ml}$ using sterilized tap water. Two methods to inoculate seeds with bacteria were used:

\section{A. Vacuum inoculation method:}

Each watermelon seed (Starbrite hybrid) was incised first using a sterilized scalpel at the micropylar end. Then, a sterilized teasing needle was used to make a shallow hole through the testa at the chalazal end of each seed. Approximately $10 \mu \mathrm{l}$ of bacterial suspension $\left(1 \times 10^{7} \mathrm{CFU} / \mathrm{ml}\right)$ was aspirated into each seed as follows using a $0.5 \mathrm{~mm}$ diameter hose. Each seed was attached to the hose at the wound at the chalazal end using a vacuum. On a sterilized petri dish lid, $10 \mu$ of the inoculum were deposited and the vacuum was used to suck the cell suspension up into the seed through the puncture at the micropylar end. Seeds inoculated with sterilized tap water were used as a negative control treatment. Inoculated seeds were air dried at room temperature overnight. Furthermore, $P$. syringae populations in each watermelon seed were confirmed immediately following inoculation. Five inoculated seeds were crushed individually in $1 \mathrm{ml}$ of sterilized tap water. The suspension was then serial diluted into $10^{-2}, 10^{-4}$ and $10^{-6}$, and one 100- $\mu$ l aliquot of each serial dilution of each seed macerate was spread-plated onto KBC medium amended with $100 \mathrm{mg} / \mathrm{ml}$ of Rifamycin. After incubation at $28^{\circ} \mathrm{C}$ for 4 to 5 days, $P$. syringae colonies were enumerated and CFU per seed was estimated (Dutta et al 2012).

\section{B. Seed soaking method}

Watermelon seeds (Starbrite hybrid) were washed with sterilized tap water, and air dried at room temperature. Seeds then were soaked in a bacterial suspension of $10^{8} \mathrm{CFU} / \mathrm{ml}$ for $1 \mathrm{~h}$, then were left on a filter paper for air dry. Seeds soaked in sterilized tap water were used as a negative control treatment. The efficacy of the seed soaking method was done as previously described in seed inoculation method.

\section{Greenhouse experiment}

Two inoculation methods (seed inoculation and spray inoculation) were used to examine the efficacy of test treatments (Multivalent (MV-Cu), fixed quaternary ammonium copper (FQ-Cu), and Kocide $^{\circledR} 3000$ ) at $50 \mu \mathrm{g} / \mathrm{ml}$ in controlling the disease before the emergence of the first true leaf, and significantly reducing the second dispersal of the inoculum.

\section{A. Seed inoculation method}

Ten inoculated watermelon seeds were placed in the middle raw of each seedling tray, surrounded by un-inoculated seedlings while total of 10 rows of each seedling tray were used. Four blocks were done while each block consists of 6 seedling trays (one tray per treatment) and the trays were arranged contiguously and distributed randomly inside each block. Control treatments consist of inoculated untreated seeds as positive control and uninoculated untreated seeds as negative control. Seedlings were managed according to industry standards as follows: After seeding, trays were 
wrapped with a plastic wrap, kept at a drying barn at $80^{\circ} \mathrm{C}$ for 3 to 4 days, then they were unwrapped and moved back to the greenhouse. Trays were irrigated daily with water using an irrigation boom at $15 \mathrm{PSI}$, where the boom was about $50 \mathrm{~cm}$ above the benches with about $20 \mathrm{~cm}$ spacing between tips. Treatments were applied 7 and 12 days after planting using the irrigation boom at $15 \mathrm{PSI}$. Disease incidence was recorded 2 days after the second treatment. During this period, asymptomatic seedlings were tested for the presence of $P$. syringae and the populations were done by randomly sampling 20 asymptomatic leaves from uninoculated seedlings in each tray, macerating them in $0.01 \mathrm{M}$ solution of $\mathrm{MgSO}_{4}$ buffer, and shaking them for $20 \mathrm{mins}$. using a shaker at $100 \mathrm{rpm} / \mathrm{min}$. The suspension then was serial diluted to $10^{-2}, 10^{-4}$ and $10^{-6}$ and was surface plated on $\mathrm{KBC}$ medium amended with $100 \mathrm{mg} / \mathrm{ml}$ of Rifamycin. Plates were incubated at $28^{\circ} \mathrm{C}$ for 4 days, then $P$. syringae colonies were counted, and the average number of asymptomatic contaminated transplants was calculated. Temperature and relative humidity were recorded during the experiment using a LogTag ${ }^{\circledR}$ humidity and temperature recorder.

\section{B. Spray inoculation method:}

Hundred watermelon seeds were placed in each tray. Four blocks were done while each block consists of 6 seedling trays (one tray per treatment) and the trays were arranged contiguously and distributed randomly inside each block. Control treatments consist of inoculated untreated seeds as positive control and uninoculated untreated seeds as negative control. Seedlings were managed according to industry standards as previously described in the seed inoculation method. Treatments were applied 7, 12 and 19 days after planting using the irrigation boom at 15 PSI. Disease incidence was recorded $6,9,11$ and 14 days after inoculation and the area under disease incidence curve (AUDIC) was calculated. Temperature and relative humidity were recorded during the experiment using a $\log \operatorname{Tag}^{\circledR}$ humidity and temperature recorder.

\section{Data analysis}

All statistical analysis was performed using JMP $^{\circledR}$ ver. 13.0.0 from SAS. Analysis of variance of the total AUDIC and \% of disease incidence was performed using the PROC GLM procedure, and Tukey's honest significant difference (HSD) was used for analysis of mean separation $(\alpha=0.05)$.

\section{RESULTS}

\section{P. syringae strain 13-1 mutant}

Colonies of $P$. syringae strain 13-1 were recovered from the NA plates amended with $100 \mu \mathrm{g} / \mathrm{ml}$ of Rifamycin.

\section{The in vitro assays}

All treatments showed an antimicrobial effect against the tested $P$. syringae isolates after $2 \mathrm{~h}$ of incubation (Fig. 1). All three tested nanomaterials and Kocide ${ }^{\circledR} 3000$ totally inhibited the growth of the copper sensitive strain 13-1 at all used concentrations. Also, the Core-Shell and the Copper fixed Quat inhibited the growth of the copper tolerant strain A1513 at all tested concentrations. Additionally, the Multivalent copper nanomaterial at 50 $\mu \mathrm{g} / \mathrm{ml}$ significantly $(P=0.05)$ reduced the growth of the strain $A 1513$ compared to the untreated control, while it completely inhibited its bacterial growth at 100,200 and $500 \mu \mathrm{g} / \mathrm{ml}$. Strain A1513 was recovered from Kocide ${ }^{\circledR} 3000$ treatments at all concentrations. Although, the bacterial population was significantly reduced $(P=0.05)$ at $500 \mu \mathrm{g} / \mathrm{ml} \mathrm{com-}$ pared to the untreated control. All nano materials at all concentrations (except Multivalent at 50 $\mu \mathrm{g} / \mathrm{ml})$ were significantly $(P=0.05)$ more effective in inhibiting the growth of the copper tolerant strain A1513 than the Kocide ${ }^{\circledR} 3000$.

\section{Validation of seed inoculation method}

Seed soaking method was significantly $(P=$ $0.05)$ more effective than the vacuum inoculation method. An average of $3.14 \mathrm{Log} \mathrm{CFU} / \mathrm{ml}$ of $P$. syringae were recovered from the watermelon seeds when using the seed soaking method, while just 2.77 Log CFU/ml were recovered when using the vacuum inoculation method (Fig. 2).

\section{Disease control in greenhouse}

\subsection{Seed inoculation}

All test treatments showed reduction of disease incidence compared to the control. MV-Cu and FQ$\mathrm{Cu}$ significantly reduced the disease incidence compared to the untreated control, while there was no significant difference between Mancozeb + Kocide $^{\circledR} 3000$ and the untreated control (Fig. 3). 


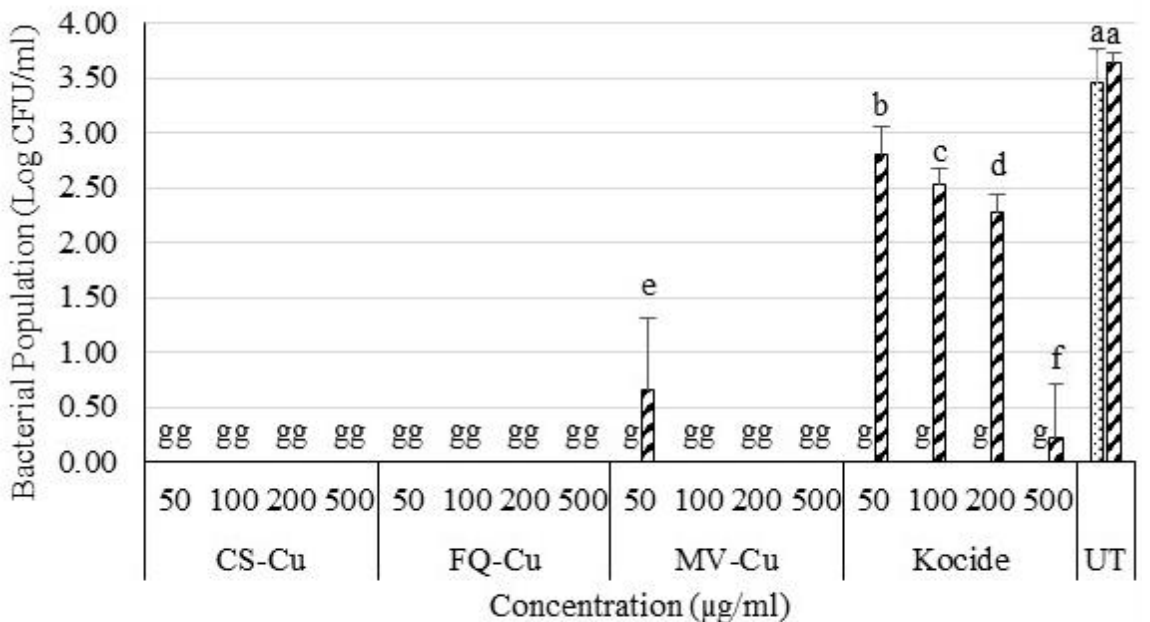

13-1 A1513

Fig. 1. In vitro assessment of different concentrations of copper (nano materials and Kocide ${ }^{(B)}$ 3000 ) on the survival of Pseudomonas syringae after $2 \mathrm{Hrs}$ of incubation. CS = CoreShell. Three replicates have been done per treatment. Error bars represent standard deviation. A $P$ value of 0.05 was used in the COSTAT least significant difference statistical analysis. Treatments with the same letter do not have a significant difference. The experiment was repeated twice and the effect of experiment was insignificant.

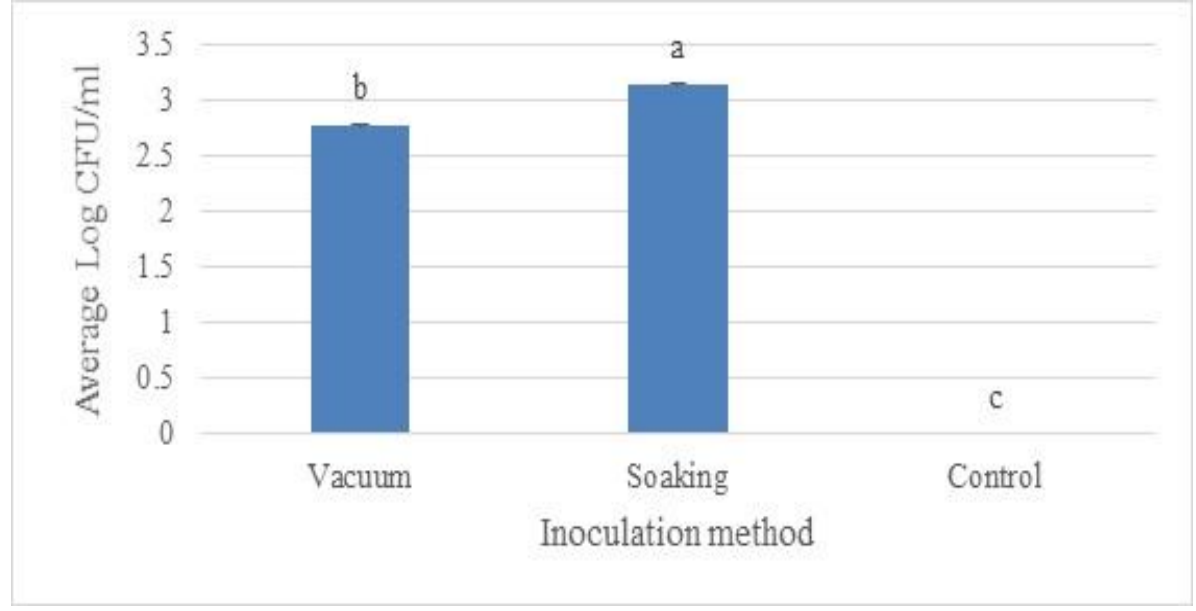

Fig. 2. Effect of different inoculation methods on average Log CFU/ml of mutated $P$. syringae strain 13-1. 


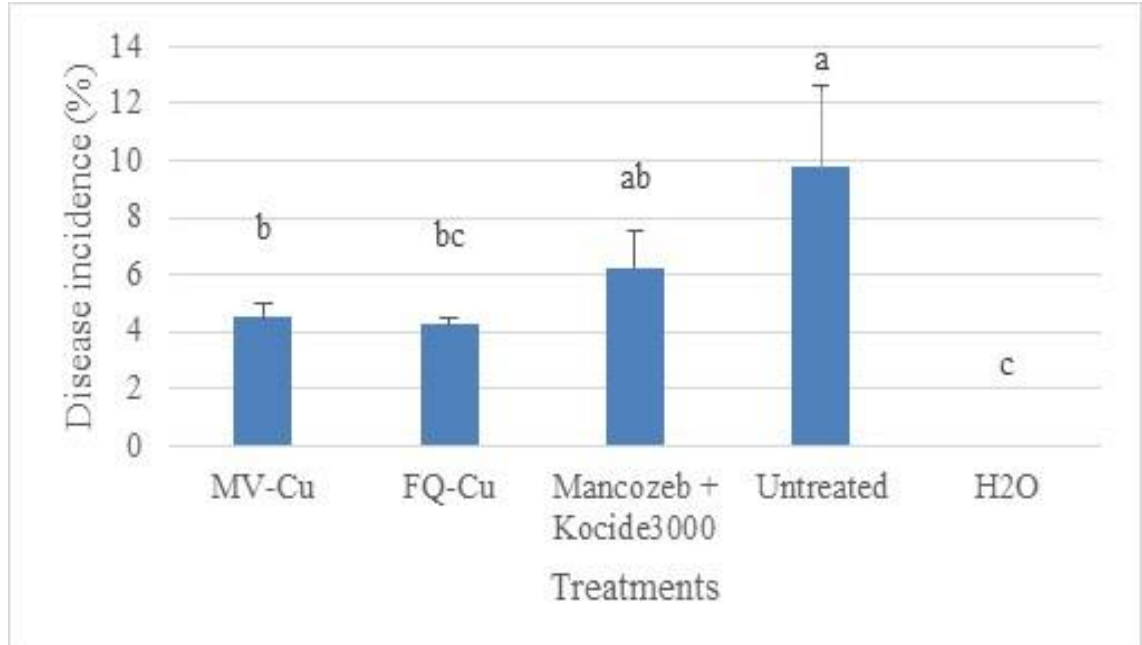

Fig. 3. Effect of different treatments on the average disease incidence among seedling flats planted with 10 infected seeds at the center of each tray.

\subsection{Spray inoculation}

The Mancozeb+Kocide ${ }^{\circledR} 3000$ was the only treatment that significantly reduced the disease incidence, while using the MV-Cu and FQ-Cu didn't significantly reduce the disease incidence compared to the untreated control. Also, there was no significant differences between all 3 test treatments (Fig. 4).

\section{Contamination rate}

All test treatments significantly reduced the contamination rate compared to the untreated control. The Mancozeb+Kocide ${ }^{\circledR} 3000$ was significantly effective in reducing the contamination rate than the MV-Cu and FQ-Cu. While there was no significant difference between the MV-Cu and FQ-Cu (Fig. 5).

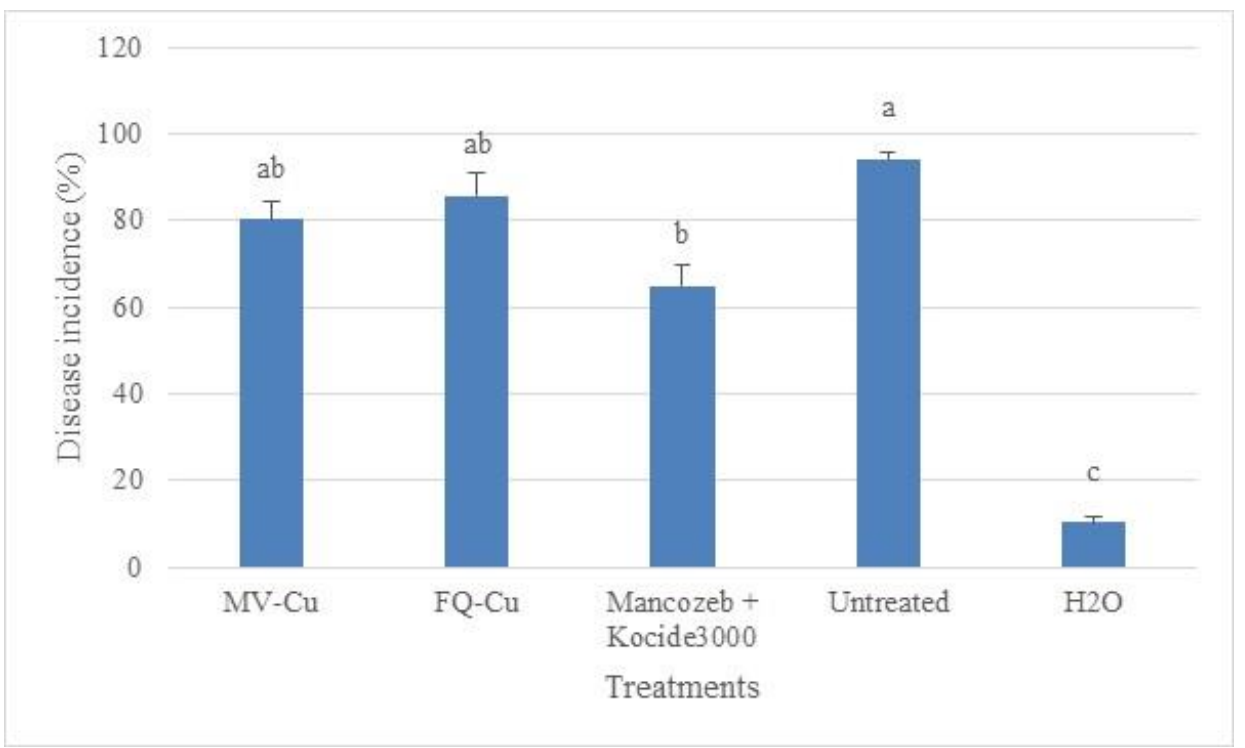

Fig. 4. Effect of different treatments on the average disease incidence among seedling flats inoculated with spray inoculation. 


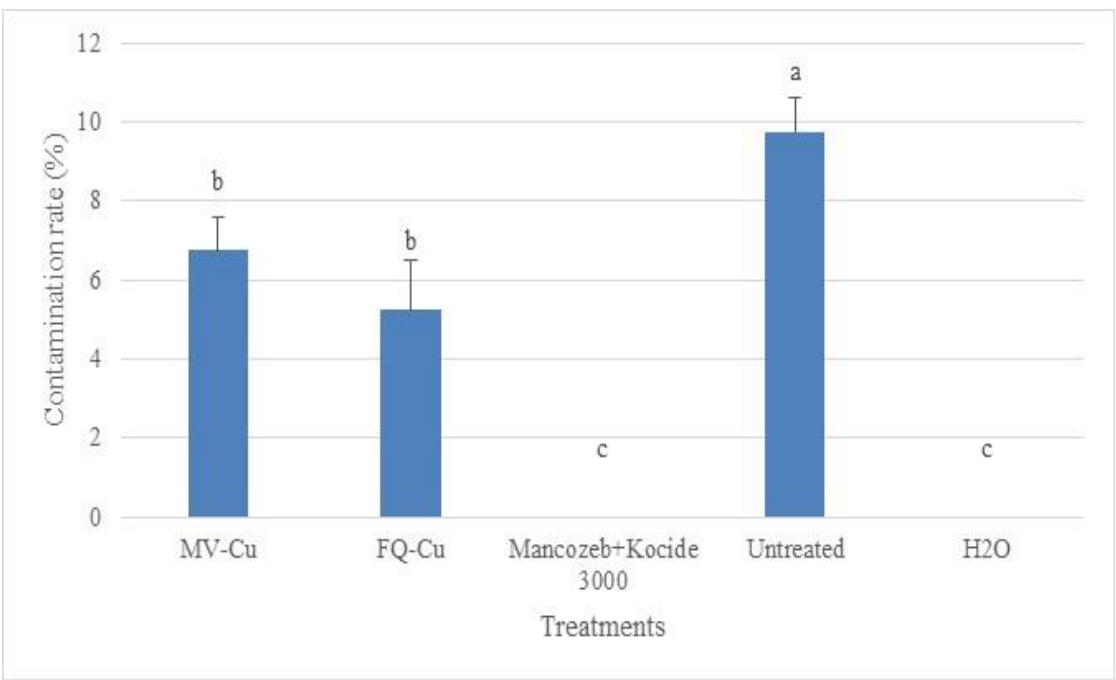

Fig. 5. Effect of different treatments on the average number of asymptomatic contaminated seedlings.

\section{DISCUSSION}

In this study, we described for the first time the antibacterial properties of three new copper composites against $P$. syringae. The composites showed potential to significantly control angular leaf spot of watermelon during the first two weeks of planting and before the emergence of the first true leaf, while even the micron-sized copper bactericides used in the management of angular leaf spot disease couldn't be applied (Dufault and Paret, 2015). This finding is significant as it was previously clarified that the use of copper compounds to control the disease before the emergence of the first true leaf is not allowed as it may cause high phytotoxicity for the plant leaves at this stage and in some cases they may help only in spreading the bacteria (Hopkins and Schenck, 1972). Not like the nano-composites because of their slow release rate of copper, phytotoxicity studies of these composites on ornamental plants (Vinica sp.) revealed that phytotoxicity is reduced in comparison to copper salts such as copper sulfate (Young and Santra, 2014).

All tested nano-composites were significantly effective in reducing the $P$. syringae population in vitro compared to the untreated control at all used concentrations. This antimicrobial effect refers to the very small size of the metallic particles in the nano composites and the high surface to volume ratio which both help in penetrating the bacterial membranes and causing more release of the metal ions (Santra, 2012), i.e. an increase in antibacterial activity against $P$. syringae was observed when the size of metallic copper was reduced from micrometers to nanometers. Using MV-Cu and FQ$\mathrm{Cu}$ at concentration of $50 \mu \mathrm{g} / \mathrm{ml}$ caused significant reduction in the growth of the copper tolerant strain A1513.

Both vacuum inoculation and seed soaking methods were significantly effective in inoculating watermelon seeds. The seed soaking method was significantly more effective than the vacuum inoculation method represented as average Log $\mathrm{CFU} / \mathrm{ml}$. Using seed soaking method may left a chance for the bacteria in the inoculum suspension to go through the seed membrane and stay in the seed, while using the vacuum method, didn't leave enough time for the bacteria to stay inside the seed, also, some inoculum suspension was noticed to be sucked in the suction tube which may have caused a low inoculum concentration inside the seeds (Dutta et al 2012).

In the greenhouse experiment, using the nanocomposites in the seed inoculation method significantly reduced the percentage of disease incidence compared to both untreated control and Mancozeb+Kocide ${ }^{\circledR} 3000$, while MV-Cu and FQCu didn't significantly reduce the disease incidence in the spray inoculation method compared to the untreated control. On the other hand, Mancozeb+Kocide ${ }^{\circledR} 3000$ significantly reduced the disease severity when seeds were spray inoculated. So, that could be a possible approach of controlling angular leaf spot of watermelon caused by infected seeds under greenhouse conditions.

The population results revealed a significant reduction of the contamination rate from infected 
seeds to uninfected seeds when using all tested treatments compared to the untreated control. There were also significant differences between both the Mancozeb+Kocide ${ }^{\circledR} 3000$ and both MV$\mathrm{Cu}$ and $\mathrm{FQ}-\mathrm{Cu}$, while there was no significant difference between MV-Cu and FQ-Cu. So, the tested nano-composites managed in significantly reducing the infection rate from infected seedlings to healthy ones during the first two weeks of planting.

\section{REFERENCES}

Baker, C., Pradhan, A., Pakstis, L., Pochan, D.J. and Shah, S.I. 2005. Synthesis and antibacterial properties of silver nanoparticles. J. Nanosci. Nanotechnol. 5, 244-249.

Bhat, N.A., Bhat, K.A., Zargar, M.Y., Teli, M.A., Nazir, M. and Zargar, S.M. 2010. Current Status of Angular Leaf spot (Pseudomonas syringae pv. lachrymans) of Cucumber: A Review. Int. J. Curr. Res. 8, 7-11.

Dufault, N.S. and Paret, M.L. 2015. Watermelon Spray uide. 2015. URL http:// programs.ifas.ufl. edu/u-scout/Tutor_files/UF_Watermelon_ Spray_Guide_2014_15.pdf

Dutta, B., Scherm, H., Gitaitis, R. and Walcott, R. 2012. Acidovorax citrulli seed inoculum load affects seedling transmission and spread of bacterial fruit blotch of watermelon under greenhouse conditions. Plant Dis. 96, 705-711.

El Sadek, S.A., Abd El Latif, M.R., Abd El Gawad, T. and Hussein, N.A. 1992. Occurrence of angular leaf spot disease in greenhouse cucumbers in Egypt. Egypt. J. Microbiol. 27, 157-175.

Elwakil, W.M. and Mossler, M.A. 2013. Florida Crop/Pest Management Profile: Watermelon. CIR1236. Gainesville: UF/IFAS, http://edis.ifas.ufl.edu/pi031. Accessed January 20, 2016.

Fanelli, V., Cariddi, C. and Finetti-Sialer, M. 2007. Selective detection of Pseudomonas syringae pv. tomato using dot blot hybridization and real-time PCR. Plant Pathol. 56, 683-691.

FAOSTAT, 2017. Food and Agriculture Organization of United Nations, Agriculture data FAO. URL http://www.fao.org/faostat/en/\#home (accessed 1.1.17).

Fatmi, M., Bougsiba, M. and Hosni, T. 2008. Angular Leaf Spot of Cucurbits: A Bacterial Disease in Expansion in Morocco, in: Pseudomonas Syringae Pathovars and Related Pathogens-Identification, Epidemiology and Genomics. Springer, pp. 381-390.
Gopalakrishnan, S., Sathya, A., Vijayabharathi, R., Varshney, R.K., Gowda, C.L.L. and Krishnamurthy, L. 2014. Plant growth promoting rhizobia: challenges and opportunities. 3 Biotech 5, 355-377.

Gunawan, C., Teoh, W.Y., Marquis, C.P. and Amal, R. 2011. Cytotoxic Origin of Copper (II) Oxide Nanoparticles: Comparative Studies and Metal Salts. ACS Nano 5, 7214-7225.

Harighi, B. 2007. Angular leaf spot of cucumber caused by Pseudomonas syringae pv. lachrymans in Kurdistan. Plant Dis. 91, 769-770.

Hopkins, D.L. and Schenck, N.C. 1972. Bacterial leaf spot of watermelon caused by Pseudomonas lachrymans. Phytopathology 62, 542545.

Jiang, W., Mashayekhi, H. and Xing, B. 2009. Bacterial toxicity comparison between nanoand micro-scaled oxide particles. Environ. Pollut. 157, 1619-1625.

Lamichhane, J.R., Messéan, A. and Morris, C.E. 2015. Insights into epidemiology and control of diseases of annual plants caused by the Pseudomonas syringae species complex. J. Gen. plant Pathol. 81, 331-350.

Langston Jr, D.B., Sanders, F.H., Brock, J.H., Gitaitis, R.D., Flanders, J.T. and Beard, G.H. 2003. First report of a field outbreak of a bacterial leaf spot of cantaloupe and squash caused by Pseudomonas syringae pv. syringae in Georgia. Plant Dis. 87, 600-601.

Maniprasad, P. and Santra, S. 2012. Novel copper $(\mathrm{Cu})$ Loaded core-shell silica nanoparticles with improved $\mathrm{Cu}$ bioavailability: Synthesis ، characterization and study of antibacterial properties. J. Biomed. Nanotechnol. 8, 558566.

Morones, J.R., Elechiguerra, J.L., Camacho, A., Holt, K., Kouri, J.B., Ramírez, J.T., Yacaman, M.J. 2005. The bactericidal effect of silver nanoparticles. Nanotechnology 16, 2346-2253.

Morris, C.E., Glaux, C., Latour, X., Gardan, L., Samson, R. and Pitrat, M. 2000. The Relationship of Host Range, Physiology, and Genotype to Virulence on Cantaloupe in Pseudomonas syringae from Cantaloupe Blight Epidemics in France. Phytopathology 90, 636-646.

Mullin, R.S. and Schenck, N.C. 1963. Bacterial leaf spot on watermelon. Plant Disease Reporter. 7(9), 848-849.

Newberry, E.A., Paret, M.L., Jones, J.B., Ritchie, L., Freeman, J.H., Dufault, N.S., Babu, B., Goss, E.M., Vallad, G.E. and Roberts, P.D. 2015. Characterization of Pseudomonas syrin- 
gae associated with watermelon and squash disease outbreaks in Florida and Georgia, Phytopathology, 8, 117-1121.

Nufram, 2013. Champ® Formula 2 Flowable. Retrieved March 2, 2016 from http:// www.nufarm.com/Assets/19430/3/Champ2F_PI B_13-AG-0020.pdf.

Quesada-Ocampo L. 2016. Pseudomonas leaf spot reported on watermelon transplants. North Carolina cooperative extension. URL https:// plantpathology.ces.ncsu.edu/2016/05/ pseudomonas-leaf-spot-reported-on-watermelontransplants/ (accessed 3.5.17).

Riffaud ،C.M.H., Glaux, C., Guilbaud, C., Prior, P., Morris, C.E. and Dominguez, H. 2003. Epidemiological Clues for Developing Methods of Control of Bacterial Blight of Cantaloupe Caused by Pseudomonas syringae pv. aptata, in: lacobellis, N.S., Collmer, A., Hutcheson, S.W., Mansfield, J.W., Morris, C.E., Murillo, J., Schaad, N.W., Stead, D.E., Surico, G., Ullrich, M.S. (Eds.), Pseudomonas Syringae and Related Pathogens: Biology and Genetic. Springer Netherlands, Dordrecht, pp. 315.

Santra, S. 2012. Silica-based antibacterial and antifungal nanoformulation. Patent No. $\mathbf{8 , 2 2 1 , 7 9 1 . ~ W a s h i n g t o n , ~ D C : ~ U . S . ~ P a t e n t ~ a n d ~}$ Trademark Office. July 17, 2012.

Santra, S., Bazata, J. and Young, M. 2014. Coreshell quaternary ammonium nanomaterials, methods and applications. U.S. Patent No. 14/248,725. Washington, DC: U.S. Patent and Trademark Office.
Sedighian, N., Shams-Bakhsh, M., Osdaghi, E. and Khodaygan, P. 2014. Etiology and host range of bacterial leaf blight and necrosis of squash and muskmelon in Iran. J. Plant Pathol. 96, 507-514.

Shila, S.J., Islam, M.R., Ahmed, N.N., Dastogeer, K.M.G. and Meah, M.B. 2013. Detection of Pseudomonas syringae pv. lachrymans associated with the seeds of cucurbits. Univ. J. Agric. Res. 1, 1-8.

Stöber, W., Fink, A. and Bohn, E. 1968. Controlled growth of monodisperse silica spheres in the micron size range. J. Colloid Interface Sci. 26, 62-69.

USDA, 2013. U.S. Watermelon Industry. URL http://usda.mannlib.cornell.edu/MannUsda/view DocumentInfo.do?documentID=1399

Williams, P.A. 1996. Angular leaf spot, in: Zitter, T.A. (Thomas A., Hopkins, D., Thomas, C. (Eds.), Compendium of Cucurbit Diseases. The American Phytopathological Society, pp. 33-34.

Young, M. and Santra, S. 2014. Copper (Cu) Silica Nanocomposite Containing ValenceEngineered $\mathrm{Cu}$ : A New Strategy for Improving Antimicrobial Efficacy of Cu Biocides Transport Properties. J. of Agric. and Food Chemistry. 62, 6043-6052.

Zitter, T., Hopkins, D. and Thomas, C. 1996. Compendium of cucurbit diseases. APS Press. 87 p. 